\title{
Construction of Knowledge Test to Measure the Knowledge of Dairy Farmers towards Clean Milk Production Practices
}

\author{
Pawan Kumar Gautam ${ }^{*}$ and Asif Mohammad ${ }^{2}$ \\ ${ }^{1}$ Dairy Extension Division, ICAR-NDRI, Karnal, Haryana, India \\ ${ }^{2}$ Dairy Extension Section, ERS of ICAR-NDRI, Kalyani, West Bengal, India \\ *Corresponding author
}

\begin{tabular}{|l|}
\hline Ke y w o r d s \\
$\begin{array}{l}\text { Knowledge test, } \\
\text { Dairy, Clean milk } \\
\text { production, } \\
\text { Farmers, Item }\end{array}$ \\
\hline Article Info \\
\hline $\begin{array}{l}\text { Accepted: } \\
\text { 10 December } 2018 \\
\text { Available Online: } \\
\text { 10 January } 2019\end{array}$ \\
\hline
\end{tabular}

\section{Introduction}

Knowledge as a body of understood information possessed by an individual or by a culture. "Clean Milk" is generally defined as "milk drawn from the udder of healthy animals, which is collected in clean dry milking pails and free from extraneous matters like dust, dirt, flies, hay, manure etc. Clean milk has a normal composition, possesses a natural milk flavor with low bacterial count and is safe for human consumption" (Sinha,
2000). Indian agriculture is characterized by the ownerships of small land holdings. The small holdings are used for mainly production of food crops.

The small farmers inadequately use fertilizers and without or meager irrigation can produce only one crop in a year, which is turn make the farmers economic condition not only pathetic also lead to inability to purchase input required for farming, like fertilizers, good quality seeds etc. 
The clean milk production following Good hygienic practices is an essential pre requisite for obtaining whole some and superior milk quality. The concept of clean milk production would be to develop sustainable, scientific and eco friendly dairy animal management based on principles of clean, green and ethical practices. The following are the pre-requisite for clean milk production and disposal. Still very little importance has been given on the quality of milk produced at farmers' household. Farmers are having very little or no knowledge about clean milk production, as well as they are not exposed to quality extension material to improve their knowledge. Thus, multimedia can be an effective tool to improve the knowledge level of farmers on clean milk production. Knowledge was operationalised as extent of information known or possessed by the dairy farmers on selected clean milk production practices.

\section{Materials and Methods}

\section{Item collection}

The knowledge test was comprised of some questions. Individual question in the knowledge test is called item. Items for the test were collected from different sources such as literature, field extension personnel, relevant specialists and researcher's own experience. In the study a total of 35 items were collected.

\section{Initial selection of items}

The selection of items was done to promote thinking of the respondents rather than to memorize the items and then replying to the items. It should promote thinking rather than mechanical memorization. It should differentiate the well informed respondents from the poorly informed ones, and should have a certain difficulty value.

\section{Pre-testing}

The items selected for the knowledge test were pre-tested separately by administering the items to 60 dairy farmers. Care was taken to see that selection of matching sample of 60 dairy farmers from non-sampling area. Sarangi (2006) reported that the knowledge level of dairy farmers regarding clean milk production was high level (16.66\%), medium level $(55.84 \%)$ and low level (27.50\%). The implementation of clean milk production practices could reduce the intensity of mastitis by $70-80$ percent and increase milk production by 0.5 to 1 litre (Rao and Rani, 2007).

\section{Item analysis}

Item analysis was carried out by administering the pre-tested items to 60 dairy farmers.

Item analysis was carried out by determining the index of 'Item difficulty' and index of 'Item discrimination'. The 'Item difficulty' indicates the extent to which an item was difficult. The function of the item discrimination index was used to find out whether an item really discriminates a wellinformed dairy farmer from poorly informed respondent.

The data thus obtained was subjected for typical item analysis. The 35 test items were administered to each one of the 60 dairy farmers. The scores assigned were 'one' for correct answer and 'zero' for incorrect response. After computing the total scores were obtained for each of the 60 dairy farmers on 35 items. They were rank ordered. Based on which the dairy farmers were then divided into six equal groups. These groups were labelled as G1, G2, G3, G4, G5 and G6 with ten dairy farmers in each group. For the purpose of item analysis, middle two groups G3 and G4 were eliminated keeping only four extreme groups with high and low scores. 
After getting the four extreme groups for item analysis, the responses for each of the items were subjected to calculate difficulty index, discrimination index and point biserial correlation as given below.

\section{Item difficulty}

It is defined as the proportion of respondents giving correct answer to that particular item. Item difficulty is an important aspect during formation of items as it should have some difficulty level that helps the farmers to understand the concept and then provide answers. It should not have very high difficulty level and also not very easier. Difficulty index range was used from 0.35 to 0.70 for the study.

$P i=\frac{n i}{N i} \times 100$

Where,

$\mathrm{Pi}=$ difficulty index in percentage of the ith item

$\mathrm{ni}=$ number of respondents giving correct answer to ith item

$\mathrm{Ni}=$ total number of respondents to whom the ith item was administered (Table 1).

\section{Item discrimination}

Calculation of discrimination index was done by following Mehta (1958). The index of discrimination indicates the extent to which an item discriminates the well informed individuals from the poorly informed ones. Discrimination index range was used from 0.30 to 0.55 for the study. The following formula was used.

$\mathrm{E}^{1 / 3}=\frac{(s 1+s 2)-(s 5+s 6)}{N / 3}$

Where, S1, S2, S5 and S6 were the frequencies of correct answers in groups G1, G2, G5 and G6 respectively
$\mathrm{N}=$ total number of respondents in the sample of item analysis

\section{Point- Biserial correlation}

This correlation coefficient was used when the variables are in dichotomous in nature. Formula for Point- Biserial correlation coefficient is given as

$\mathrm{r}_{\mathrm{pb}}=\frac{M p-M q}{\sigma} \times \sqrt{p q}$

Where, $\mathrm{Mp}$ and $\mathrm{Mq}=$ means of two categories $\mathrm{p}=$ proportion of the sample in the first group

$\mathrm{q}=$ proportion of the sample in the second group

$\sigma=$ standard deviation of the entire sample

Selected items to measure the knowledge of dairy farmers towards clean milk production practices

1. Which nutritional element is present in milk?
a. Nitrogen
b. Calcium

2. Which vitamin is present in milk?
a. Vitamin A
b. Vitamin C

3. What is the amount of potassium permanganate required for preparation of 1 litre solution?
a. $10 \mathrm{~g}$
b. $20 \mathrm{~g}$

4. Which disease occurred due to infection of udder?
a. TB
b. Mastitis

5. Feeding of milch animals should be made

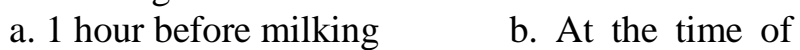
milking

6. After cleaning of milking utensil must be kept in
a. Sunlight
b. In the room

7. Cleaning of animal shed should be done
a. Weekly
b. Daily

8. Stagnated water near animal shed resulted in
a. Bad smell to milk
b. Good smell to milk 
9. Which milking method is good for animal health?
a. Full hand method
b. Knuckling method

10. For the transportation of milk, utensil should be used
a. Open mouthed
b. Closed mouthed

11. Animal should be washed thoroughly
a. Weekly
b. Every day

12. Which utensil should be used for milking purpose?
a. Stainless steel
b. Plastic

13. Milk man should wash their hands
a. Before milking
b. After milking

14. Which part of the animal should be tied during milking?
a. Tail
b. Legs

15. Knuckling method of milking results in the a. Injuries on teats b. Does not injure

16. Animal should not sit immediately after milking for 30 minutes which helps to

a. Avoid contamination b. Increase contamination

17. Which disease can be spread from human to animal?
a. Communicable disease
b. Any disease

18. Potassium permanganate available in the markets
a. Powder form
b. Liquid form

19. Cleaning of animal teat should be done

a. before and after milking

before milking

b. Only

20. Clean milk can be transported over
a. Long distance
b. Short distance

21. What should be used be used during transferring of milk?

a. Sieveb. Sieve not required

\section{Results and Discussion}

\section{Representativeness of the test}

Care was taken to see that the test items selected finally covered the entire universe of the relevant behavioural aspects of dairy farmer's knowledge about clean milk production practices. Girish Deshmukh and Ashok Pagar (2014) found that the cleanliness of milch animals occupied first position, it was because of the farm women doing animal husbandry since generation and they know the importance of cleanliness of milch animals. They took enough care of their cows and buffaloes as they earned additional income for their family and they treated their cows and buffaloes as the family members might be the reason for this finding.

\section{Selection of the items}

Out of 35 items, 21 items were finally selected based on; Items with difficulty level indices ranging from 35 to 70 . Items with discrimination indices ranging from 0.30 to 0.55 . Items having significant point biserial correlation either at 1 percent or 5 percent level. Thus, the finally selected knowledge items comprising multiple choices, totaling to 21 items of test battery on knowledge of clean milk production practices.

\section{Reliability of the test}

The split half method was used to calculate the reliability of developed knowledge test on clean milk production. Odd number items and even number items were segregated and subsequently correlation value of two sets of data was calculated and the value was 0.68.Spearman-Brown formula was used to calculate the reliability coefficient of the whole test. The reliability coefficient of the whole test was 0.81 which was significant at 1 percent level of significance. 
Table.1 Difficulty index, discrimination index and reliability value of different test items

\begin{tabular}{|c|c|c|c|c|}
\hline $\begin{array}{l}\text { S. } \\
\text { No. }\end{array}$ & Statement & $\begin{array}{l}\text { Difficulty } \\
\text { index } \\
(35-70)\end{array}$ & $\begin{array}{c}\text { Discrimination } \\
\text { index } \\
(\mathbf{0 . 3 0 - 0 . 5 5 )}\end{array}$ & rpb \\
\hline 1 & $\begin{array}{l}\text { Which nutritional element present } \\
\text { in milk }\end{array}$ & 52.08 & 0.37 & $0.9892^{*}$ \\
\hline 2 & Which vitamin is present in milk & 39.58 & 0.50 & $0.9893^{*}$ \\
\hline 3 & $\begin{array}{l}\text { What is the amount of potassium } \\
\text { permanganate required for } \\
\text { preparation of } 1 \text { liter solution }\end{array}$ & 41.66 & 0.50 & $0.9894^{*}$ \\
\hline 4 & $\begin{array}{l}\text { Which disease occur due to } \\
\text { infection of udder }\end{array}$ & 41.66 & 0.50 & $0.9894 *$ \\
\hline 5 & Clean milk is free from & 75.00 & -0.1250 & NS \\
\hline 6 & $\begin{array}{l}\text { Feeding of milch animals should be } \\
\text { made }\end{array}$ & 35.41 & 0.37 & $0.9892 *$ \\
\hline 7 & $\begin{array}{l}\text { After cleaning of milking utensil } \\
\text { must be kept in }\end{array}$ & 41.66 & 0.31 & $0.9894 *$ \\
\hline 8 & $\begin{array}{l}\text { Cleaning of animal shed should be } \\
\text { done }\end{array}$ & 54.16 & 0.37 & $0.9894 *$ \\
\hline 9 & $\begin{array}{l}\text { Stagnated water near animal shed } \\
\text { resulted in }\end{array}$ & 39.58 & 0.50 & $0.9893 *$ \\
\hline 10 & $\begin{array}{l}\text { Which milking method is good for } \\
\text { animal health }\end{array}$ & 35.41 & 0.50 & $0.9892^{*}$ \\
\hline 11 & $\begin{array}{l}\text { After milking, milk should be kept } \\
\text { at }\end{array}$ & 100.00 & 0 & NS \\
\hline 12 & $\begin{array}{l}\text { For the transportation of milk, } \\
\text { utensil should be used }\end{array}$ & 64.58 & 0.37 & $0.9894 *$ \\
\hline 13 & $\begin{array}{l}\text { Feeding material provided to the } \\
\text { animals having }\end{array}$ & 1 & 0 & NS \\
\hline 14 & $\begin{array}{l}\text { Animal should be washed } \\
\text { thoroughly }\end{array}$ & 58.33 & 0.43 & $0.9894 *$ \\
\hline 15 & $\begin{array}{l}\text { Milking utensil should be cleaned } \\
\text { by }\end{array}$ & 1 & 0 & NS \\
\hline 16 & Clean milk production helps in & 1 & 0 & NS \\
\hline 17 & $\begin{array}{l}\text { Animal teats should be cleaned } \\
\text { which helps in }\end{array}$ & 1 & 0 & NS \\
\hline 18 & $\begin{array}{l}\text { Which utensil should be used for } \\
\text { milking purpose }\end{array}$ & 58.33 & 0.50 & $0.9894^{*}$ \\
\hline 19 & Milk man should wash their hands & 62.50 & 0.31 & $0.9894^{*}$ \\
\hline 20 & $\begin{array}{l}\text { Use of oil before milking resulted } \\
\text { in }\end{array}$ & 0 & 0 & NS \\
\hline 21 & $\begin{array}{l}\text { Which part of the animal should be } \\
\text { tied during milking }\end{array}$ & 47.91 & 0.50 & $0.9894 *$ \\
\hline
\end{tabular}




\begin{tabular}{|c|c|c|c|c|}
\hline 22 & $\begin{array}{l}\text { Knuckling method of milking } \\
\text { results in the }\end{array}$ & 20.80 & 0.06 & NS \\
\hline 23 & $\begin{array}{l}\text { Unhealthy feeding material is the } \\
\text { cause of }\end{array}$ & 1 & 0 & NS \\
\hline 24 & $\begin{array}{l}\text { Now a days pure milk is not } \\
\text { available, the reason is }\end{array}$ & 1 & 0 & NS \\
\hline 25 & $\begin{array}{l}\text { Animal should not sit immediately } \\
\text { after milking for } 30 \text { minutes, which } \\
\text { helps in }\end{array}$ & 35.41 & 0.43 & $0.9892 *$ \\
\hline 26 & $\begin{array}{l}\text { Which disease can be spread from } \\
\text { human to animal }\end{array}$ & 41.66 & 0.50 & $0.9894 *$ \\
\hline 27 & $\begin{array}{l}\text { Potassium permanganate available } \\
\text { in the markets }\end{array}$ & 35.41 & 0.37 & $0.9892 *$ \\
\hline 28 & $\begin{array}{l}\text { Cleaning of animal teats should be } \\
\text { done }\end{array}$ & 45.83 & 0.37 & $0.9894 *$ \\
\hline 29 & Clean milk is having & 1 & 0 & NS \\
\hline 30 & Clean milk can be transported over & 66.66 & 0.31 & $0.9896^{*}$ \\
\hline 31 & $\begin{array}{l}\text { What product can be made from } \\
\text { milking by churning }\end{array}$ & 1 & 0 & NS \\
\hline 32 & Milk man should be & 1 & 0 & NS \\
\hline 33 & $\begin{array}{l}\text { What should not be used before } \\
\text { milking }\end{array}$ & 0 & 0 & NS \\
\hline 34 & $\begin{array}{l}\text { What should be used during } \\
\text { transferring of milk }\end{array}$ & 43.75 & 0.50 & $0.9893^{*}$ \\
\hline 35 & Intake of clean milk makes person & 1 & 0 & NS \\
\hline
\end{tabular}

*Significant at $1 \%$ or $5 \%$ level of significance

NS-Non-significant

\section{Validity of the test}

Content validity of the test was ensured as all the items of knowledge test was developed through consultation with experts in the field and by making use of scientific literatures. The content of the test entirely covered different facets of clean milk production. It was assumed that the score obtained by administering the knowledge test of this study measures level of knowledge of dairy farmers towards clean milk production practices.

Thus the knowledge test developed in the present study can measure the knowledge of dairy farmers towards clean milk production practices as it showed the greater degree of reliability and validity.

\section{Administration of the test}

All the 21 items in the knowledge test read out to the respondents after establishing rapport with them. The respondents were asked to answer the items by themselves.

Following are the statements on level of knowledge of dairy farmers towards clean milk production. Please give your answers to these questions.

\section{References}

Deshmukh, G. and Pagar, A. 2014. Practice wise knowledge and adoption of clean milk production by dairy farm women in Junagadh district. The Asian 
journal of animal $\quad$ science.9: 182188.

Rao,K.R.and Rani,K.S.2007. Technology upgradation for sustainable dairy development. Indian dairyman.59 (8):39-43.

Ray,G.L. and Mandal, S. 2014. Research methods in social sciences and extension education. Kalyani publishers, New Delhi.

Sarangi, A. 2006. Knowledge management for improving CMP practices among landless dairy women of Haryana through interactive multimedia. Unpublished Ph.D. thesis. National Dairy Research Institute, Karnal, India.

Sinha, O.P. 2000. Clean milk production and support practices. FAO E-mail conference on small-Scale

\section{How to cite this article:}

Pawan Kumar Gautam and Asif Mohammad. 2019. Construction of Knowledge Test to Measure the Knowledge of Dairy Farmers towards Clean Milk Production Practices. Int.J.Curr.Microbiol.App.Sci. 8(01): 1183-1189. doi: https://doi.org/10.20546/ijcmas.2019.801.124 